\title{
Shaping the worship of the Reformed Church in Geneva: Calvin on prayer and praise
}

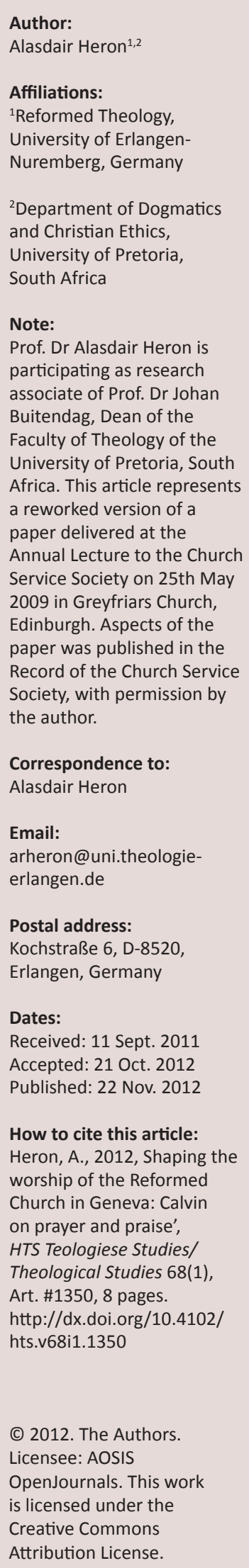

The article aims to investigate the Calvin's Genevan Service Order. It focuses on the question how the Psalter Calvin shaped the worship of the Reformed Church in Geneva. The article follows the critical edition of the Genevan prayer in Calvini Opera Selecta and in the German Studienausgabe as the two main published editions of the Genevan order with its related texts. The article shows that Calvin adhered to the general line of the Swiss and Upper German Reformations. It explores the understanding of worship reflected in the Genevan Service Order and the specific significance of its musical aspect. The article illustrates why Calvin gave the psalms the place he did in Genevan Reformed worship.

\section{Introduction}

CLOWN: She hath made me four-and-twenty nosegays for the shearers, - three-man songmen all, and very good ones; but they are most of them means and bases; but one puritan amongst them, and he sings psalms to hornpipes. (Shakespeare, The Winter's tale IV.2, c. 1610-1611)

It is without a doubt meet, right and our duty in the Church Service Society to remember John Calvin and his impact on Reformed worship at the occasion of the 500th anniversary of his birth even if we cannot but also remember that the foundation of this society goes back to a widespread uprising in the nineteenth century against the style and practices of Calvinist worship as they had largely dominated Scots Presbyterianism till then (and still to some extent prevail in continental Reformed worship, as I discovered on going from Edinburgh to Erlangen 28 years ago).

\section{Calvin's great undertaking}

I would like, however, to bracket off that issue for the moment and concentrate rather on looking again at how, in his Genevan Service Order and the Psalter, Calvin actually did approach and carry through the task of shaping the worship of the Reformed Church in Geneva. As the history of the texts involved here is somewhat complicated, with the results of serial expanded new editions leading to ever greater length but not necessarily greater transparency on a first sighting of the modern republications (cf. Baum, Cunitz \& Reuss [1867] 2012, Corpus Reformatorum 34:161-209), it may be helpful to follow the example of the critical edition in Calvini Opera Selecta (cf. Barth \& Scheuner 1952; La Forme 1-10; 11-58) and the German Studienausgabe (Busch 1997; cf. Marti 1997:137-146, 148-255; Maxwell 1931, 1936; Lamb 1962). The summary of the main editions is on page 142-143 in the introduction by Marti. This introduction is an excellent account of Calvin's liturgical aims, and I take the liberty here of drawing heavily upon it. Reference should also be made here of the classic studies by members of the Society in former generations. The main published editions of the Genevan order with its related texts are indicated here: ${ }^{1}$

1533: William Farel's La Maniere et fasson quon tient en baillant le sainct Baptesme [...], published in Neuchâtel and with a second edition in 1538.

1539/40: Calvin's Strasbourg Order of Worship. This did not survive, but Calvin refers to it in his farewell address to the ministers of Geneva on 28 April 1564 as the main source for the Genevan Sunday prayers and form for Baptism.

1542: $\quad$ The first Genevan edition of La Forme des Prières et Chantz ecclésiastiques (Calvin [1542] 1959 , edited by P. Pidoux). Only one original copy of the 1542 edition is known to exist (cf. Marti 1997:148-225). This is in the Württembergische Landesbibliothek in Stuttgart ${ }^{2}$. There is a facsimile edition of this 1542 book by Pidoux La forme des prières et chantz ecclésiastiques (The form of songs and prayers in the church) which appeared in Kassel and Basel (1959). A second edition (now lost) seems to have appeared in 1543: Its Epistre au Lecteur (dated 1543 and expanding that of 1542) survives in later editions.

1.Both these editions indicate from which source the different strands of material are taken.

2.This was the state of information when Marti compiled his edition and also when this lecture was delivered in May 2009. At the autumn 2009 meeting of the Presbytery of Europe in Lausanne, however, Felix Allender of the Genevan congregation told me of a letter of 09 July 2009 which he received from the Director of the Landesbibliothek informing him of the existence of another copy in the HenriArnaud-Haus/Waldensermuseum in Ötisheim. 
1542a: An edition of the Strasbourg liturgy claiming to be 'Imprime a Rome par le commandement $d u$ Pape' and therefore known as the Pseudoromana. Such ruses were commoner then than might be thought today. For example, Robert Horne, the Bishop of Winchester, had his Certaine homilies translated and published in 1553, just after the accession of Mary had made the publishing of evangelical books hazardous. It was therefore published as being '[i]mprinted at Rome before the castle of S. Angel at the signe of St. Peter' (Parker 1992:73). The edition of the Strassbourg liturgy was formerly ascribed to Calvin, but Jenny (1968:115) holds that the editor, Pierre Brully, Calvin's successor in the French congregation in Strasbourg, also made his own significant contribution. It is probably a revised edition of Calvin's liturgy of 1539-1540. This supersedes the view still reflected in Maxwell (1936:112-119) that the Strasbourg editions of 1542 and 1545 were Calvin's work. Useful as Maxwell's study still is as an analysis of the structure and elements of the various orders he compares and parallels in this section, he does not in fact go into these texts in much detail. However he does, unlike Marti (1997:137-146, 148-255) in his introduction, emphasise the dependence of Calvin's work on Bucer's German Strasbourg liturgy of 1537-1539, which he reproduces extensively (Maxwell 1936:87-112) as well as tracing Calvin's influence (via Knox) on 'The Reformed Rites and their Successors in Scotland' (Maxwell 1936:120-136).

1545: A further edition of the Strasbourg order, altered and expanded, but also using the Genevan texts of 1542 and 1543 . However, this can only be regarded as an indirect testimony to Calvin's work. The one surviving copy was destroyed in the Franco-Prussian War in 1870. The Strasbourg Psalter of 1545 included the French original of the hymn 'I greet Thee, who my sure Redeemer art', which has sometimes been attributed in whole or in part to Calvin, for example in the American Presbyterian Hymnal of 1990 (No. 457) or in Cahiers d'histoire (No. 86). The attribution does not, however, seem very secure in view of the likelihood that this Strasbourg order was two stages removed from Calvin's own (cf. ed. Barkley 1979:97).

1546: A new edition of La Forme appears, without a place-name but presumably in Geneva.

1559: The Psalms and the service texts are bound together with the Genevan Bible.

\section{The history of the Genevan psalter}

The history of the emergence of the Genevan Psalter is similarly complex. According to Marti (1997:161), the rhymed psalms in the development of the Genevan Psalter in the Forme of 1542 represented a second stage. He indicates that it was preceded by Calvin's Strasbourg Psalter, Aulcuns Pseaulmes et cantiques, with texts by Calvin and by Clément Marot. The Genevan edition of 1542 still includes texts by Calvin, but they are already at the third stage, the only indirectly accessible edition of 1543 (Cinquante psaumes, preserved in a text print of 1543 and a Lyons reprint of 1548/49). These versions were all replaced by Marot versions. Two further stages followed, Pseaumes octantetrois in 1551 with additional texts by Théodore de Bèze and the complete Psalter of 1562, again with further texts by the same author. Pierre Pidoux (ed. 1986) also edited a facsimile of the 1562 Psalter.

Alongside the two poets of the texts stand three composers, namely for the editions of 1542 and 1543 presumably the chantre, that is the cantor and music teacher in the school, Guillaume Franc. Those in the edition of 1551 are attributed to the famed composer Loys Bourgeois, and for the last series, one 'Maître Pierre le chantre', perhaps Pierre Davantès, is supposed to have been the composer.

Bourgeois is by far the best known of the three. He was a Hugenot composer who wrote, compiled and edited many melodic settings of Psalms in the Genevan Psalter. He was a friend of Calvin and lived with him (1545-1557). Bourgeois was made a citizen of Geneva in 1547 but, in 1551, was imprisoned for a day for tampering with the accepted Psalm tunes without authorisation. Calvin secured his release, and eventually Bourgeois's alterations were approved. Bourgeois based his Psalm settings on French texts by the celebrated poet Clément Marot and the leading theologian Théodore de Bèze (Beza). Though his harmonisations were not widely popular, the melodies he created were used by many later composers. Bourgeois used fragments of popular tunes and possibly also of liturgical chant in his melodies, the most familiar of which is Psalm 134, known as 'Old Hundredth'. He was himself responsible for about 85 melodies in the Psalter, which was completed by his successors in 1562. Besides contributing to the Psalter, Bourgeois was one of the first to propose (in Le Droict Chemin de musique, 1550) learning to sing by means of solfeggio (note syllables, as do, $\mathrm{re}, \mathrm{mi}, . .$.$) in place of the then-standard Guidonian hand, a$ method of learning notes by associating them with parts of the hand (Greene 2007:42). The psalms used at Strasbourg were published in 1539 Aulcuns pseaulmes et cantiques mys en chant. Some psalms and canticles were arranged for singing (Parker 1975:88. The Aulcuns pseaulmes et cantiques mys en chant contained nineteen psalms, the Nunc dimittis, the Ten Commandments and the Credo. Twelve of the psalms were adaptations from an unpublished collection by Clément Marot. The rest of the psalter seems to have been the work of Calvin himself.

The origin of the tunes, printed only as the melody line, has not been traced, but it is thought that Matthias Greiter of Strasbourg at least compiled and arranged them. From the end of 1542, Clément Marot was a refugee in Geneva. He did not enjoy the city, and he did not stay long. He did, however, write another nineteen metrical psalms, some of which Calvin substituted in the 1543 Psalter for his own inferior 
versions. Of equal value with Marot was another refugee, Louis Bourgeois, who lived and taught music in Geneva for sixteen years from 1541 . How derivative his hymn tunes are it is very hard to say, but they admirably fulfilled Calvin's demand for weight and majesty. Some have taken their place in modern hymn-books, and very fine they are, even in their edited harmonies in Hymns Ancient and Modern; is not the 'Old Hundredth' unsurpassed amongst hymn tunes?

Later came friction between the composer and Calvin, who disliked harmony in congregational singing, no doubt as detracting from simplicity: All that is needed in the praise of God is a pure and simple modulation of the voice. Bourgeois' harmonised Psalter had therefore to be printed in Lyon instead of Geneva. The third edition of the Handbook to the Church Hymnary (in Marti 1997:161) offers a little more detail on the disagreements. Towards the end of 1551, Bourgeois was thrown into prison for making unauthorised alterations to certain well-known tunes. Calvin, albeit remonstrating with him, secured his release after twenty-four hours. Other troubles followed, and finally, failing to induce his employers to allow the introduction of part-singing into public worship, Bourgeois left Geneva and returned to Paris.

One melody in the Psalter, namely that to Psalm 36 and 68, is an only slight reworking of the Strasbourg melody to Psalm 119, composed by Matthäus Greiter (Marti 1997:140-141; cf. Pidoux's facsimile edition for the final version of the Psalter, Les psaumes en vers français avec leurs melodies) (Pidoux [1562] 1986).

\section{Calvin's work in Geneva and Strasbourg}

Before we come to look at these texts more closely, it is worth noting that Calvin's general position remained remarkably constant throughout his decades of work in Geneva and Strasbourg. A characteristic early discussion of the celebration of the Lord's Supper (which Calvin consistently regarded as the normative form of weekly worship) in the 1536 Institute reappears with only occasional minor alterations ${ }^{3}$ in every edition up to the fourth and final (Latin) edition of 1559. Marti (1997:137) draws attention to this and summarises the main points, but for our purposes, it may be useful to quote the text in full as it reveals many of Calvin's characteristic emphases and convictions (Institute IV.17.43):

But as for the outward ceremony of the action - whether or not the believers take it in their hands, or divide it among themselves, or severally eat what has been given to each; whether they hand the cup back to the deacon or give it to the next person; whether the bread is leavened or unleavened; the wine red or white - it makes no difference. These things are indifferent, and left at the church's discretion.

However, it is certain that the practice of the ancient church was for all to take it in their hands. And Christ said, 'Divide it among yourselves' [Luke 22:17, Vulgate]. The histories narrate that common leavened bread was used before the time of the Roman bishop Alexander, who was the first who delighted in

3.The order of the blocks of material is altered in 1559 by comparison with 1536 (Opera Selecta I.161), but otherwise there is substantial verbal identity between that text and Inst. IV.17.43 (Calvin 1559). unleavened bread. But I see no reason for this, unless to draw the eyes of the common people to wonderment by a new spectacle, rather than to instruct their minds in sound religion. I ask all who are in the least affected by a zeal for piety whether they do clearly see both how much more brightly God's glory shines here, and how much richer sweetness of spiritual consolation comes to believers, than in these lifeless and theatrical trifles, which serve no other purpose than to deceive the sense of a people stupefied. They call this the holding of people by religion when they lead them at will - dulled and befooled by superstition. If anyone should like to defend such inventions by appealing to antiquity, I also am not ignorant of how ancient the use of chrism and exsufflation is in baptism; how soon after the apostolic age the Lord's Supper was corrupted by rust. But this, indeed, is the stubborn boldness of men, which cannot restrain itself from always trifling and wantoning in God's mysteries. Let us, however, remember that God so esteems obedience to his Word that he would have us judge both his angels and the whole world in its light [I Cor. 6:2-3; Gal. 1:8].

Now, to get rid of this great pile of ceremonies, the Supper could have been administered most becomingly if it were set before the church very often, and at least once a week. First, then, it should begin with public prayers. After this a sermon should be given. Then, when bread and wine have been placed on the Table, the minister should repeat the words of institution of the Supper. Next, he should recite the promises which were left to us in it; at the same time, he should excommunicate all who are debarred from it by the Lord's prohibition. Afterward, he should pray that the Lord, with the kindness wherewith he has bestowed this sacred food upon us, also teach and form us to receive it with faith and thankfulness of heart, and, inasmuch as we are not so of ourselves, by his mercy make us worthy of such a feast. But here either psalms should be sung, or something be read, and in becoming order the believers should partake of the most holy banquet, the ministers breaking the bread and giving the cup. When the Supper is finished, there should be an exhortation to sincere faith and confession of faith, to love and behaviour worthy of Christians. At the last, thanks should be given, and praises sung to God. When these things are ended, the church should be dismissed in peace.

\section{The Swiss and upper German reformations}

Although when he first penned these words ${ }^{4}$ Calvin had not yet had, as far as we know, any great experience in the organisation, planning and conducting of worship (Parker 1992:57-58), ${ }^{5}$ it is clear (and not perhaps surprising, since he was living in Basle at the time) that his approach to the celebration follows the general line of the Swiss and Upper German Reformations. Unlike the Lutheran and Anglican (and earlier Strasbourg) liturgical reforms, these Reformations did not simply purify the liturgy of the Mass whilst retaining its basic structure and many of its elements in a modified Eucharistic order. Instead, they adopted a model of worship deriving from the late medieval Pronaus or Prone, originally a non-sacramental form of vernacular service based on prayers and preaching (cf. Pahl 1983:5, 347-367). Marti (1997)

4.Presumably in 1535, as the dedicatory epistle to Francis I was dated in August of that year.

5.Parker summarises the fairly scanty records of Calvin's preaching before 1536 (drawn from Colladon's Vie de Calvin of 1565). 
expounds this point well, emphasising at the same time that Calvin developed this tradition further in a fashion new in the history of liturgy by incorporating the Decalogue, Lord's Prayer and Creed as a 'kind of Ordinarium' (Jenny 1968:133) to frame the constitutive elements of prayer, preaching and communion. This is not necessarily apparent in the 1542 Forme, which is a sometimes confusing compilation of material, but is shown at the latest by a psalm table added to the Lyons Psalter of 1549. Marti (1997) offers the following sketch:

The course of the Genevan liturgy is clearly determined by the chief elements we have named. After beginning with an opening word, confession of sins and a sung psalm the sermon follows as the first focal point. The Decalogue leads over to the extended prayer section with intercessions, the Lord's Prayer or a paraphrase thereof and the prayer before Communion. The Creed then leads into Communion, consisting of the Words of Institution, the excommunication of the unworthy, the distribution and the prayer of thanksgiving, after which the service closes with the Nunc dimittis and the blessing .... It was actually Calvin's intention to celebrate the service every Sunday in its complete form, thus with Communion. However, this was not possible in Geneva, so the order of service also already visualises a conclusion after the prayer of intercession. (pp. 138-139)

The structure of the 1542 Forme includes (Marti 1997:141, 145-146):

- letter to the reader (extended in 1543 with further sections on music and singing)

- musical section ${ }^{6}$

- prayers for the Sunday service

- baptism

- the Lord's supper

- marriage

- visitation of the sick.

The letter to the reader, both in the shorter 1542 and the longer 1543 version, seeks to give an account of the aims and intentions of this pattern of worship, as do the explanations of the reform of baptism and of the Lord's Supper at the end of the respective sections. These are much of a piece with Calvin's remarks in the Institute quoted above. Thus on baptism, Marti (1997) states:

We know that elsewhere many additional ceremonies are carried out, which we will not deny to be ancient. But because they were invented simply to please or at least for trivial considerations - however it was: as they were fabricated without the Word of God and on the other hand because so many superstitions arose from them, we have had no difficulty in abolishing them, so that no barrier should any longer hinder the people from going directly to Christ. First of all, what God has not commanded lies within our freedom and everything which does not contribute to edification should not be accepted in the church or, if it was accepted earlier, be removed again .... Now it is clear that anointing, candles and other such customs are not drawn from God's ordinance but have been added by men .... Thus we at least have the form of Baptism which Jesus Christ ordained, the Apostles and their followers preserved and the primitive church used. So we cannot be accused of anything except that we do not desire to be wiser than God. (pp. 193-195, 213-215)

6.This section is not reprinted by the Opera Selecta or Marti, but the Opera Selecto $(6-8)$ lists the Psalms given in the 1542 and 1542a editions - the lists are largely but not entirely identical.
The fairly heavily didactic tone is hard not to notice. Indeed, as has often been remarked in more modern times, the starkly instructional bias of this and similar Reformed orders in the sixteenth century is both marked and, however understandable under the conditions of the time, not always their most attractive feature for modern hearers or worshippers. In the forms of 1542 (and also 1542a and 1545), this shows itself most prominently in the amount of space devoted in the order for the Lord's Supper to the exclusion of the unworthy, the call to self-examination and the explanation of the meaning of the Supper itself - all this in the place and at the point where other liturgies (including our modern ones in the Church of Scotland) would more usually have the Eucharistic prayers. Such prayers as the order does offer for the Supper also sound pronouncedly instructional (Marti 1997:173-175). By contrast, the baptismal prayer could still be used without too much change (Marti 1997):

Lord God, eternal and almighty Father, it has pleased you in your unending goodness to promise us that you will be our God and the God of our children. We ask you to confirm this grace in this child, whose father and mother you have called to your church. We bring and dedicate it to you to be taken up into your holy protection, that you declare yourself its God and Saviour and forgive the original sin of which the whole seed of Adam is guilty. Then may you sanctify it by your Holy Spirit that when it comes of age to understand it may recognise and worship you as its only God and glorify you in its whole life, so to receive the forgiveness of sins ever and again. And finally may it receive the grace of being engrafted in the communion of Jesus Christ, that it may have part in all his benefits as a member of his body. Hear us, Father of mercy .... (p. 187)

However, this is preceded by an address on the meaning of baptism which is some five times as long as the prayer. Calvin was not Cranmer! As I said earlier, however, this is not the subject I wish to dwell upon here, though I am far from regarding it as unimportant.

\section{Calvin's understanding of worship}

Instead, I would like to explore two areas further. One is the understanding of worship reflected in this order. The other is the specific significance of its musical aspect. Both are addressed at some length in the 'Letter to the Reader'. The letter is fairly long - not for the introduction to a book of order, but for full quotation in an article - but some excerpts may give a fair picture. First, on the understanding of worship:

Our Lord did not give the order which we ought to maintain when we gather in his name in order to give people entertainment in gaping and gazing; rather he wished that profit should arise for his whole people. [...] But that can only be if we are instructed so that we understand all that has been ordered for our benefit. For it is a poor joke - as they say - to say that we can still have devotion in prayer or public worship without understanding anything. True affection for God is no dull or dead thing but a living movement proceeding from the Holy Spirit by which the heart is directly touched and the understanding enlightened. For if we could be edified by things we only see without understanding what they mean, Paul would not so strictly have forbidden speaking in unknown tongues nor argued that there is no edification save where there is teaching. So if we wish to 
hold the ordinances of our Lord which we use in the church in proper honour, the main thing is to know what they contain, what they mean and what they intend: only so is their usage useful and salvific and consequently properly ordered. (Marti 1997:151-153)

The letter goes on to say that there are altogether three things we are commanded to observe in worship: proclamation of the Word, solemn public prayer and the administration of the sacraments. Preaching is not the subject here, but the other two are, and with both what is central is the comprehended Word:

[W] have the explicit command of the Holy Spirit that the prayers are to be made in the common language understandable by the people; and the Apostle says that the people cannot answer with 'Amen' if the prayer is spoken in a strange language. Because it is spoken in the name and on behalf of all, all must be able to take part in it. It was therefore a great shamelessness on the part of those who introduced Latin in the churches where it could not generally be understood. And no subtlety or cavils can excuse them from the charge that this style is perverse and displeasing to God ....

Now to the sacraments: if we attend well to their nature we shall recognise that it is a perverse custom to celebrate them in such a way that the people has nothing but the view of them without exposition of the mysteries they contain. For if they are visible words, as Augustine names them, then they cannot merely be an external spectacle, but the doctrine must be conjoined to make them understood. [...] We need make no long dispute about this. If the matter is viewed dispassionately there will be no-one who does not admit that it is a pure card trick to amuse the people with signs whose meaning is not explained.

[I] $\mathrm{t}$ is commonly assumed that the consecration both of the water of baptism and of bread and wine in the Lord's Supper is a kind of enchantment. That is, they think that when the mouth whispers and utters the words, the insensible elements feel the power which the people do not. However, the true consecration is that which takes place in the word of faith when it is proclaimed and heard, as Augustine says. That is also expressly contained in the words of Jesus Christ. He does not tell the bread to become his body but addresses his word to the company of the faithful saying 'Take, eat etc'. So if we desire to celebrate the sacrament properly we need the doctrine to declare to us what it means.

I know very well that this view seems very strange to those not accustomed to it: it is like that with everything new. But it is obvious that we as disciples of Jesus Christ must prefer his institution to our custom. Nor ought what he instituted at the beginning be looked on by us as a new fashion.

If not everyone can yet understand this, we must pray God to be pleased to enlighten the ignorant that they may see how much wiser he is than all the men on earth. So may they learn not to remain stuck in their own understanding nor in the crazy and rabid wisdom of their blind guides. (Marti 1997:153-155)

It is striking that the burden of these paragraphs is largely a somewhat forceful assertion of Reformed obedience to the Word of God combined with harsh criticism of the Roman use of Latin and the widespread magical understanding of the sacraments. What prayer and sacraments are, or why they are performed, is not spelt out as it is elsewhere by Calvin, most extensively in the Institute (Inst. III.20 on prayer; IV.14-19 on the sacraments). In that sense, these paragraphs conform to the same pattern as the explanations at the end of the sections on baptism and the Lord's Supper; they are polemically apologetic and didactic. The concluding paragraph of the letter in 1542 is slightly different in tone, for here the subject is prayer spoken and sung:

$[N]$ ow so far as common prayer is concerned, it has two forms. Some are framed in simple words, the others in song. That is no modern invention; it was so from the first beginnings of the church, as history makes clear. Paul himself speaks not only of spoken prayer but also of sung. And truly, we know from experience that singing has great force and power to move and enflame the hearts of people so that they call upon and praise God with more vehement and ardent zeal. It must always be observed that the singing is not light and fluttering but has weight and majesty, as St. Augustine [Confessions X.33] says. Thus there should be a great difference between the music that is made for people to enjoy at table and in their homes and the psalms that are sung in church before God and his angels. Whoever justly judges the form of singing presented here will hopefully find it to be holy and pure, for it is directed solely to the edification of which we spoke. (Marti 1997:155-157)

A year later, in June 1543, Calvin apparently was convinced that it is desirable to say rather more on this subject and to offer more by way of positive explanation. We can perhaps only speculate on the reasons behind this: Had he had to face criticism of this new practice of psalm-singing or had he been confronted with abuses in practice? This led to the expansion of the 'Letter to the Reader' by the addition of the new section, which reads as follows:

The use of song reaches widely. Even in our homes and on the field it should be an incitement and as it were an organ to praise God and lift our hearts to him, to comfort us by meditating on his power, goodness, wisdom and justice. That is more needful than one can say. In the first place it is not without reason that the Holy Spirit exhorts us through the Holy Scriptures to rejoice in God and to direct all our joy to him as its true goal. For he knows how much we are inclined to rejoice in vanity. Just as our nature drags and induces us to seek every means of foolish and vicious pleasure, so our Lord by contrast offers us all possible means of the spiritual joy he enjoins to distract and withdraw us from all temptations of the flesh and the world.

Among all the things adapted to recreate humans and bring them delight, music is the first or at least one of the most important, and we have to regard it as a gift given by God to this end. We should therefore keep an eye on ourselves that we do not misuse it, for fear of soiling and contaminating it by twisting it to our damnation when it was really given for our benefit and salvation. Even if there were no other consideration than this, it alone should lead us to regulate ${ }^{7}$ the use of music, to let it serve all that is honourable and give us no occasion to loosen the bridle to dissolution or to make us soft in disordered delights, so that it is not an instrument of vice or of any kind of shamelessness.

Yet there is more. There is scarcely anything else in the world that can twist and turn human morals in the one or the other direction, as Plato [Republic III] extensively demonstrates. And we do in fact experience that it has a hidden and almost unbelievable capacity to move the heart in the one or the other way.

7.Marti (1997:157-159) notes that Calvin's verb 'moderer' should not be interpreted as 'moderate' in a restrictive sense: ' $E$ s geht jedoch nicht um eine quantitative Einschränkung der Musik (auch nicht bei der Anordnung, im Gottesdienst solle ausschließlich einstimmig und ohne Instrumente gesungen werden), gleichsam ausschließlich einstimmig und ohne Instrumente gesungen werden), gleichsam
einen halbherzigen Kompromiss bei der Zulassung von Musik, sondern um ihre qualitative Bestimmung, wie sie gleich anschließend beschrieben wird. ' 
Therefore we must be all the more careful so to regulate music that it benefits and in no way harms us. It is for this reason the ancient teachers of the church so often complain that the people of their times gave themselves to indecent and impudent songs. Not without cause did they regard these as deadly, satanic poison which would corrupt the world.

When I speak here of music, I mean both parts, namely the letter as the subject and matter, and secondly the song or the melody. It is true as Paul says that every evil speech corrupts good morals, but when the melody is added it pierces the heart even more and enters into it just as wine is poured through a funnel into the cask. Just so are poison and corruption transported by melody into the depths of the heart.

What then is to be done? We need to have songs which are not only honourable but also holy. They should spur us on to prayer and the praise of God, to meditation on his works, so that we love, fear, honour and glorify him. For what Augustine [Psalmos sermo 1] says is true: that no-one can sing anything worthy of God if he has not received it from God himself. Therefore we can seek here and there where we like: we shall find no better and more suitable songs than the psalms of David which the Holy Spirit spoke to him and made. When we sing them we can be sure that God himself puts the words in our mouths as if he himself were singing in us to exalt his glory. That is why Chrysostom exhorts both men, women and little children to accustom themselves to sing them so that this should become a kind of meditation to associate them with the company of angels.

It remains to remind ourselves of what Paul says: that spiritual songs can only rightly be sung with the heart (Eph 5:19; Col. 3:16.). But the heart requires the understanding. That is the difference (as Augustine [Psalmos 18] said) between human song and that of the birds. A linnet, a nightingale, a parrot may sing well, but without comprehension. The distinctive gift of humans is to sing knowing what they say: heart and feeling should follow the understanding. But that is only possible if we have impressed the song upon our memory so that we never need to stop singing. ${ }^{8}$

For this particular reason (as well as everything else we have said) this book deserves to be singularly recommended to everyone who desires to rejoice honourably in accordance with God with a view to his own salvation and the benefit of his neighbours. So it scarcely needs to be specially recommended by me as it carries its value and gain in itself. Only everyone would be well advised to accustom himself by it to sing the divine and heavenly psalms of King David instead of songs that are sometimes trivial and frivolous, sometimes stupid and gross, sometimes sordid and ugly and therefore bad and harmful. As far as the melodies are concerned, it seemed best to arrange them in the style in which we have cast them. This gives them weight and majesty appropriate to their theme and makes them fit to sing in church in the way described. (cf. Marti 1997157-161)

Marti (1997:157-161) comments on this quote and, regarding Calvin's understanding of worship and the role of music, he states that, in La forme, Calvin never used a specific liturgical term for the worshipping assembly which could be translated with 'divine service'. He uses neither culte nor service, liturgie nor office. The closest he gets is the formulation of 'public prayer'. For Calvin, the assembly for worship does not represent any special sacral time, but it is integrated within the Christian life and this is to be understood in its totality as 'before the face of God'. In the same way, no distinction can be drawn between the Christian congregation and a worldly or political community to be defined in distinction from it. This must be taken into account if the role of music is to be properly assessed. Contrary to a widespread opinion that is sometimes also to be found in academic literature, Calvin by no means restricted the role of music in worship but enriched the non-musical service as he found it existing in Geneva with the singing of psalms - and this was his intention from the very beginning as the proposal for the singing of psalms in public prayer in the Articles of 1537 shows. Regarding this, Reid (1954) states:

On the other hand there are the psalms which we desire to be sung in the Church, as we have it exemplified in the ancient Church and in the evidence of Paul himself, who says it is good to sing in the congregation with mouth and heart. We are unable to compute the profit and edification which will arise from this, except after having experimented. Certainly as things are, the prayers of the faithful are so cold, that we ought to be ashamed and dismayed. The psalms can incite us to lift up our hearts to God and move us to an ardour in invoking and exalting with praises the glory of his Name. Moreover it will be thus appreciated of what benefit and consolation the pope and those that belong to him have deprived the Church; for he has reduced the psalms, which ought to be true spiritual songs, to a murmuring among themselves without any understanding. (pp. 53-54)

\section{Calvin and the psalter}

Calvin gave a glowing commendation of the psalms as prayer in the introduction to his Commentary on the Psalms in 1557 (cf. ed. Freudenberg's [2008] 'Foreword, in Calvin Studienausgabe, Band 6: Der Psalmenkommentar. Eine Auswahl).

This psalm-singing in turn has its place not only in the Sunday assembly, but also 'in our homes and on the field', as Calvin wrote in the expansion of the Introduction which we suspect belongs to 1543 . Not too much weight must therefore be laid on the fact that, in the service, the psalms were only sung in unison and without instrumental accompaniment. Behind that lies no principle of 'hostility to art' (Pidoux 1991:139-159), as is shown by the appearance from the beginning of harmonised arrangements, motets and lute accompaniments to the rhyming psalms which were intended for use in home and school. It is rather a matter of the location of the various forms of music appropriate to their situation and function. Practical grounds already suggested unison singing in the service in view of the widely lacking tradition of artistic musical harmony and the difficult acoustic conditions in St Pierre. But then the service represents a concentration of life before God in prayer and proclamation and communion; the music that is used is correspondingly distilled to its fundamental elements, word and melody. It is therefore not at all a matter of a reduction but of a concentration in the interest of the appropriate dignity. The influence of the Platonic and Augustinian understanding of music can certainly be seen here: Precisely the powerful effect of music on the human soul demands a planned shaping and application of this medium. This leads to the fact that the melodies of the Genevan Psalter were composed according 
to strict rules, which gives them a powerful unity in spite of their various sources and their three different composers. At the same time the compositional input and with it the artificial (in the sense of 'artifice') character is significantly higher than in the songs of the German Reformation with their closer orientation to popular music. The artistic character of music in the humanist sense is thus more strictly maintained in the Genevan Reformation then anywhere else. Calvin also differs clearly from Luther in the function he ascribes to music. If for Luther the character of proclamation, indeed the pedagogical and catechetical task stood in the forefront, ${ }^{9}$ Calvin assigns music exclusively to prayer. It should 'inflame the hearts' and, by drawing in the affective dimension, form indeed help to constitute prayer as a special and especially intensive speechform. Prayer as a language pointing beyond the human level of communication demands a shape transcending mere speech (Marti 1997:139-140).

\section{Conclusion}

I do not mean to suggest that none of Marti's interpretations are open to discussion, but for myself as a musically interested non-musicologist, I have found his account extremely illuminating. Above all, he helps to give us a better understanding of what Calvin thought he was doing in compiling the Genevan Forme and driving on the production of the Psautier. Whether Calvin's intentions and the form in which he carried them out can give us the sole adequate model for worship today is, as I have occasionally hinted, another question. Rather than end on that note, however, I would rather give Calvin the last word by quoting from the 'Foreword' to his Commentary on the Psalms of 1557:10

It is hard to express in words how many shining riches this treasury [the Psalter] contains. I at least realise that all my words fall far short of their dignity. Since however it is better to give the reader at least a small foretaste of such a great store than to remain silent, I may be permitted to indicate briefly what for the magnitude of the matter I cannot perfectly present.

For good reasons I am accustomed to call this book an anatomy of all parts of the soul. For every emotion that one can feel finds its reflection in this mirror. Yes, here the Holy Spirit brings vividly near to us all the pains, sadness, fears, doubts, hopes, cares, terrors, confusions, in short all the feelings by which the human mind is tossed. The remainder of Scripture contains the commandments which God gave to his servants to proclaim to us. But here the prophets themselves speak with God and because they bring their secret thoughts to light they speak to each of us and lead us to self-examination. So none of the many weaknesses to which we are subject and none of the many faults in which we abound remains hidden. It is a rare and singular gain when all the hidden places have been searched out and the heart is brought to light, freed of the corruption of hypocrisy. If after all prayer to God is the strongest support of our salvation, we can nowhere else find a better and more trustworthy guide than in this book. Everyone who makes good progress in understanding it will attain a fair measure of heavenly wisdom. Sincere prayer

9.Marti refers here to Luther's words in the introduction to the Deutsche Messe of 1526: For the sake of the simple people 'one must read/sing/preach/write and 1526: For the sake of the simple people one must read/sing/preach/write and compose poetry/and where it was helpful as a means to that end/I
bells sound/and all the organs play/and everything ring that can.'

10.I follow here the edition in Calvin, Studienausgabe Band 6: Der Psalmenkommentar. Eine Auswahl. The 'Foreword' was edited and translated by Matthias Freudenberg. is born first of awareness of our need and second of trust in the promises. Here readers are stirred up in the best way to feel their deficiencies and be told what remedies to seek. Yes, everything which prayer to God can contribute to our animation is shown us in this book. For we do not only meet promises; instead the worshipper often shows himself here in the tension between the invitation of God and the impediments of the flesh. If sometimes doubts torture us, we should learn to struggle so long until our liberated spirit rises to God. And not only that: even in the midst of doubt, fear and trepidation we should make every effort to pray until we can rejoice in consolation. For it is certain: even when distrust closes the door to our prayers, we dare not let go even when our hearts are disturbed and shaken by unease, until our faith goes forth as victor from its conflicts. At many places we can observe how God's servants in prayer were made so unsure that they by turns were almost overcome and yet after a hard battle emerged victorious. There on the one hand is shown the weakness of the flesh, but on the other the power of faith unfolds. Even when this power is not so strong as we might wish, it is still at least prepared to struggle until it finally reaches solid strength.

Since however guidance to proper prayer is scattered through the whole book, I will neither burden readers through superfluous repetition nor delay their reading on. Admittedly it seems to me worth the trouble to remark in passing that the book lays before our eyes one thing to be desired above all: not only that familiar access to God lies open before us, but that we may openly confess before him our weaknesses which we are ashamed to admit to men. We also find here the right prescription for offering appropriately the sacrifice of praise which God himself pronounces the most rich and fragrant. Nowhere else can one read from a greater fullness of shining praise both for the singular beneficence of God to the Church and for all his works. Nowhere else are so many acts of liberation recounted or such glorious testimonies to his fatherly care and providence towards us. Finally, nowhere else do we learn so much about the way in which we should praise God or receive stronger encouragement to fulfil the responsibilities of our faith. Although this book is so full of prescriptions for leading a holy, pious and just life, yet it teaches us in the chief place to bear the cross. That is the proper test of our obedience when we surrender our own inclinations, submit to God and allow our life to be so directed by him that even the heaviest burdens become pleasant because they come from God. Finally we do not only hear here hymns of praise for God's goodness in general to guide pious souls to come to rest in God alone, so that in every need they can expect sure help from him. Much more: the forgiveness of sins through grace which alone reconciles us and establishes for us rest and peace with God is so laid upon our hearts that we now miss nothing necessary to recognise eternal salvation.

Calvin goes on from here to emphasise the special affinity he feels to David, and that leads in turn to the autobiographical section of the introduction. But that need not be repeated here. The paragraphs we have quoted serve illuminatingly to show why Calvin gave the psalms the place he did in Genevan Reformed worship.

\section{Competing interests}

The author declares that he has no financial or personal relationship(s) which may have inappropriately influenced him in writing this article. 


\section{References}

Augustinus, [396-430], Corpus scriptorum ecclesiasticorum Latinorum 33, Tempsky, Vienna.

Barkley, J.M. (ed.), 1979, Handbook to the Church Hymnary, 3rd edn., Oxford University Press, Oxford.

Barth, E.P. \& Scheuner, D., 1952, Joannis Calvini Opera Selecta Vol. 2. Tractatus Theologicos minores ab anno 1542 usque ad annum 1564 editos continens, Chr. Kaiser, Munich.

Busch, E., 1997, Calvin Studienausgabe Bd II. Gestalt und Ordnung der Kirche, Neukirchener Verlag, Neukirchen-Vluyn.

Baum, G., Cunitz, E., \& Reuss, E., [1867] 2012, 'Series II: Ioannis Calvini, Opera Quae Supersunt Omnia - Volumes 29-87', Corpus Reformatorum, in Theopedia: An Encyclopedia of Christianity, viewed 19 October 2012, from www.theopedia. com/Corpus_Reformatorum

Calvin, J., [1542] 1959, La forme des prières et chants ecclésiastiques, ed. P. Pidoux, Bärenreiter, Basel.

Calvin, J., 1960, 'The Institutes of the Christian Religion', McNeill/Battles edn., in Christian Classics Ethereal Library, viewed 19 October 2012, from http://www. ccel.org/ccel/calvin/institutes.ii.i.html

Freudenberg, M. (Hrsg.), 2008, Calvin Studienausgabe, Band 6: Der Psalmenkommentar. Eine Auswahl, Neukricherner Verlag, Neukirchen.

Greene, D.M., 2007, Greene's biographical encyclopedia of composers, vol. 1, ed. A.M. Petrak, reproducing Piano Roll Foundation, The Foxtail Group, Santee, CA.
Jenny, M., 1968, Die Einheit des Abendmahlsgottesdienstes bei den elsässischen und schweizerischen, Reformatoren, Zurich.

Lamb, J.A., 1962, The Psalms in Christian worship, Faith Press, London.

Marti, A., 1997, 'Introduction', in E. Busch (ed.), Calvin Studienausgabe, Band II: Gestalt und Ordnung der Kirche, pp. 137-146, 148-225, Nukirchener Verlag, Neukirchen-Vluyn.

Maxwell, W.D., 1931, John Knox's Genevan Service Book, Oliver and Boyd, Edinburgh Maxwell, W.D., 1936, An outline of Christian worship, Oxford University Press, London. Parker, T.H.L., 1975, John Calvin, J.M. Dent \& Sons Ltd, London. Parker, T.H.L., 1992, Calvin's preaching, T \& T Clark, Edinburgh.

Pidoux, P. (Hrsg.), [1952] 1986, Der Genfer Psalter, World Council of Churches, Geneva. Pidoux, P., 1991, 'La Genève de Calvin et le chant des psaumes', Revue musicale de Suisse Romande XLIV, 139-159.

Plato [427-34 BCE] 1974, Plato Republic, transl. D. Lee, 2nd edn., Penguin Books, London.

Reid, J.K.S., 1954, 'Articles concerning the Organization of the Church and of Worship at Geneva in 1537', in Calvin: Theological treatises, translated with Introductions and notes by J.K.S. Reid, pp. 47-54, SCM Press, London.

Pahl I. 1983 , Coena Domini I. Die Abendmah/sliturgie der Reformationskirchen im 16./17 Jahrhundert, Universitätsverlag, Fribourg. (Spicilegium Friburgense 29).

Shakespeare, W., 1610-1611, The Winter's Tale, 1986 edn., Penguin books, London. 